Vol. 24, No. 4, pp. 344 355, 2021.

\title{
A Review of Electrochemical Cells with Geometrically Well-defined Interfaces for Solid Oxide Fuel Cell Anodes

\author{
Yoonseok Choi ${ }^{1 \dagger}$ \\ ${ }^{1}$ Energy Materials Laboratory, Korea Institute of Energy Research (KIER), Daejeon, 34129, Republic of Korea
}

\section{모델 전기화학 셀을 이용한 고체산화물 연료전지 연료극 반응 연구}

\author{
최윤석 ${ }^{\dagger}$ \\ 1한국에너지기술연구원 에너지소재연구실
}

(Received November 15, 2021; Accepted November 30, 2021)

\begin{abstract}
s
A solid oxide fuel cell (SOFC) is a high-temperature (above $750^{\circ} \mathrm{C}$ ) energy conversion device that generates electricity with high efficiency and low $\mathrm{CO}_{2}$ emission. It is essential to develop high-activity electrodes for its commercialization by lowering the operating temperature to below $700^{\circ} \mathrm{C}$. Understanding the electrode reaction kinetics can provide fundamental insights for the rational design of high-performance electrodes. However, the three-dimensional porous microstructures of the SOFC electrodes make it difficult to analyze the reaction processes precisely. To overcome this issue associated with the conventional electrodes, the model electrodes with geometrically well-defined interfaces have been widely employed. In this paper, focusing on the SOFC anodes, the fabrication techniques, cell types, analysis tools, and the modeling studies in the literature will be reviewed.
\end{abstract}

Keywords: Solid oxide fuel cells, model electrodes, anode, high-temperature electrochemical reaction, ceramic thin-film

†Corresponding Author: yschoi@kier.re.kr / +82-42-860-3558 


\section{1. 서론}

연료전지 (Fuel cell)는 연료의 화학에너지를 전기에 너지로 직접 변환시키는 에너지 변환 장치로, 일반적 인 카르노식 열기관의 효율 한계를 극복하여 고효율 전 기 생산이 가능하고 공해 문제로부터 크게 자유로운 친 환경 발전 장치이다. ${ }^{[1]}$ 특히 $750^{\circ} \mathrm{C}$ 이상의 온도에서 작 동하는 것을 특징으로 하는 고체산화물 연료전지 (solid oxide fuel cell, $\mathrm{SOFC}$ )는 높은 전기효율과 생성된 과 잉열을 열병합 발전에 활용할 경우 전체 효율이 $80 \%$ 이 상으로 증가시키는 것이 가능하다. ${ }^{[2,3]}$ 또한 내부 개질 을 통해 천연가스, 바이오매스 등의 연료를 직접 주입하 여 운전할 경우 연료전지의 이상적인 연료인 수소 공급 이 경제성을 지니기 전 현재의 인프라 기반의 고효율 발 전을 통해 경제적 이익을 제공하고 환경오염을 최소화 할 수 있다는 점에서 많은 관심을 받고 있다. ${ }^{[4-6]}$

일반적으로 $\mathrm{SOFC}$ 는 주로 산소이온 $\left(\mathrm{O}^{2-}\right)$ 전도성 $\mathrm{Y}$ 안정화 지르코니아 (Yttria-stabilized $\mathrm{ZrO}_{2}$, YSZ)나 $\mathrm{Gd}$ 이 첨가된 세리아 $\left(\mathrm{Gd}\right.$-doped $\left.\mathrm{CeO}_{2}, \mathrm{GDC}\right)$ 등의 고 체산화물 전해질을 기반으로, 전해질 양면에 각각 연료 와 공기가 주입되는 연료극과 공기극으로 구성되어 있 다. Fig. 1 에 보이는 바와 같이 $\mathrm{SOFC}$ 의 작동은 각 전 극에서의 연료의 산화반응 식 (1)과 공기의 환원반응 식 (2), 그리고 전해질을 통한 공기극으로부터 연료극으로 의 $\mathrm{O}^{2-}$ 의 전도 및 외부 도선을 따라 연료극으로부터 공
기극으로의 $\mathrm{e}^{-}$흐름을 통해 최종적으로 전기와 물, 그리 고 열을 생성함으로써 이루어진다 식 (3).

$$
\begin{aligned}
& 2 \mathrm{H}_{2}(\mathrm{~g})+2 \mathrm{O}^{2-}=2 \mathrm{H}_{2} \mathrm{O}(\mathrm{g})+4 \mathrm{e}^{-} \\
& \mathrm{O}_{2}(\mathrm{~g})+4 \mathrm{e}^{-}=2 \mathrm{O}^{2-} \\
& 2 \mathrm{H}_{2}(\mathrm{~g})+\mathrm{O}_{2}(\mathrm{~g})=2 \mathrm{H}_{2} \mathrm{O}(\mathrm{g})
\end{aligned}
$$

$\mathrm{SOFC}$ 의 상용화를 위한 주요 연구개발 방향 중 하나 는 작동온도를 중저온 $\left(500-700^{\circ} \mathrm{C}\right)$ 영역대로 낮추는 것 으로, 이는 고온의 환경이 열화학 내구성이 높은 고가의 소재를 사용하도록 제한하고 열화로 인한 장기 수명 문 제를 야기함과 함께 전반적인 시스템 제작 - 운영을 더 욱 복잡하게 하여 가격을 상승시키기 때문이다. ${ }^{[7]}$ 그러 나 $\mathrm{SOFC}$ 의 작동온도가 낮아짐에 따라 열적 활성 과정 인 이온 물질 전달과 전극 표면 반응 속도가 크게 저하 되어 그 성능이 급격히 감소되는 문제가 발생한다. ${ }^{[8-10]}$ 특히 상대적으로 큰 활성화에너지 (activation energy, $E_{A}$ )를 갖는 전극 분극 저항 (electrode polarization resistance, $\left.R_{P}\right)$ 으로 인해 중저온 영역에서 전극의 성능 이 전체 $\mathrm{SOFC}$ 의 성능에 큰 영향을 미친다. 뿐만 아니라 전극 지지형 셀을 활용하여 전해질의 두께를 수 $\mu \mathrm{m}$ 까지 낮출 수 있게 되면서 고성능의 $\mathrm{SOFC}$ 전극을 개발하는 것이 관련 연구에서 작동온도를 낮추는 데 더욱 중요한 역할을 하게 되었다.
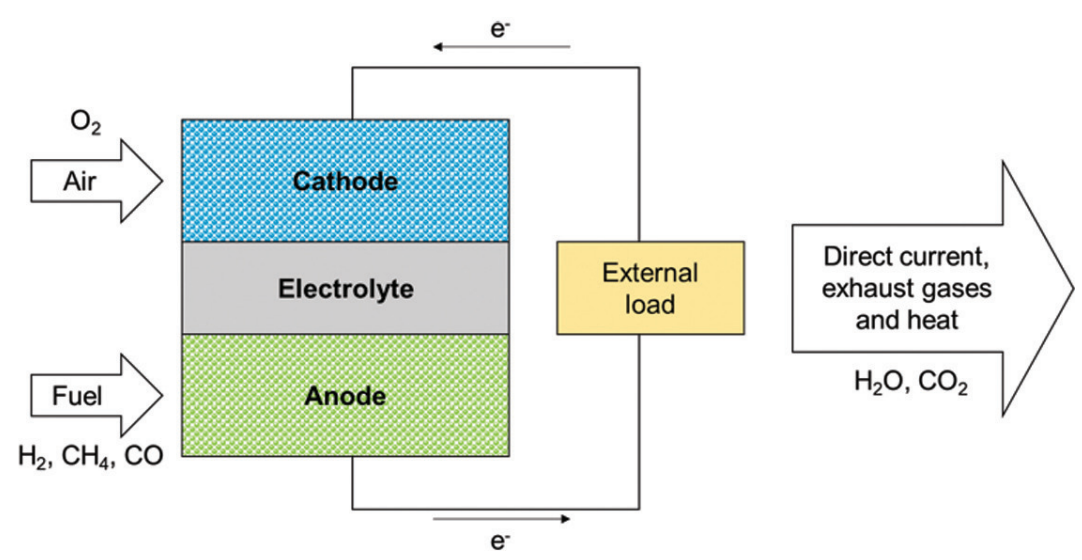

Fig. 1. Schematic depicting the basic structure and operation principle of SOFCs. 


\section{특 집 ㅍㅃ 최윤석}

이러한 관점에서 전극에서 발생하는 전기화학 반응을 심도 있게 이해하는 것은 수많은 실험적 시행착오로부 터 벗어나 고성능 $\mathrm{SOFC}$ 전극 설계를 위한 근본적인 통 찰력을 제공할 수 있기 때문에 매우 중요하다. 그러나 위 반응식 1 과 2 를 통해 표현된 바와 같이 각 전극 반응 에는 기체 분자, 이온, 그리고 전자가 동시에 수반될 뿐 만 아니라 실제로는 여러 기본 단계 (elementary step) 로 복잡하게 진행되므로 이를 정확히 이해하는 것이 매 우 어렵다. 또한 전극은 높은 전기화학적 성능을 얻기 위해 각 물질을 빠르게 운반할 수 있는 전도성 소재들의 3 차원 다공성의 구조로 구성되어 있기 때문에 실제 반응 이 일어나는 활성 영역을 정량적으로 파악하거나 활성 반응 영역에서의 반응 과정만을 선택적으로 관찰하는 것이 더욱 어렵다.

지난 수십년간 많은 연구자들은 이 문제를 극복하여 실험적으로 전극 반응 매커니즘을 규명하고 성능 향상 을 위한 이론적 근거들을 제시하기 위한 다양한 연구들 을 수행해왔다. 한 가지 유용한 접근법은 구조적으로 잘 제어된, 단순화된 계면을 갖는 전극을 이용한 모델링 연 구이다. ${ }^{[11]}$ 단순화된 전극 구조를 활용할 경우 활성 계면 을 정량적으로 파악하는 것이 가능하고, 전극 반응에 참 여하는 물질 전달을 단순화하거나 전극 전반에 걸쳐 균 일하게 함으로써 일반적인 전극 내 불균일한 구조적 인 자로 인해 본질적으로 발생하는 실험적 오차로부터 자 유로워질 수 있다. 본 투고문에서는 실제 $\mathrm{SOFC}$ 의 연료 극을 모사한 모델 전극 기반의 전기화학 셀에 대하여 구 조, 제작 방법, 그리고 이를 다양한 분석 기법과 결합함
으로써 전극 소재 특성을 명확히 파악하거나 반응에 대 한 속도 결정단계 등을 규명하는 연구 사례들을 정리하 고 소개하고자 한다.

\section{2. 모델 전기화학 셀}

\subsection{SOFC 전극의 활성 계면}

전극 소재가 어떤 전하 운반체 (charge carrier)를 전 달하는가에 따라 달라지는 전극 반응의 주요 활성 계 면을 분류하여 이해하는 것은 모델 전기화학 셀을 어 떻게 설계·제작·분석할 것인지를 결정하는 데 중요 이다. ${ }^{[12]}$ 먼저 일반적으로 전극은 순수 산소이온 전도 성 물질 (pure ionic conductor)과 순수 전자 전도성 물 질 (pure electronic conductor)의 복합체로 구성할 수 있는데, 전자의 경우 대게 전해질과 동일한 조성의 금 속 산화물이고 후자의 경우는 환원분위기의 연료극에서 는 금속, 산화분위기의 공기극에서는 페로브스카이트 (perovskite)계 금속 산화물이 각각 주로 사용되고 있 다. 예를 들어, $\mathrm{SOFC}$ 의 가장 일반적인 연료극은 순수 산소 이온 전도성 YSZ 전해질과 전자 전도성 $\mathrm{Ni}$ 금속의 복합체로 구성되어 있다 (Ni-YSZ cermet). ${ }^{[15]}$ 따라서 이 경우 전기화학적 반응은 연료 기체와 YSZ 그리고 $\mathrm{Ni}$ 의 세 가지 상이 동시에 만나는 3상계면 (triple-phase boundary, TPB)에서 발생한다 (Fig. 2a). 한편 일부 소 재들로부터 산소이온과 전자를 동시에 운반할 수 있는 혼합전도 특성이 보고되었으며, 이러한 혼합전도성 산 화물 (mixed ionic and electronic conductor, MIEC)
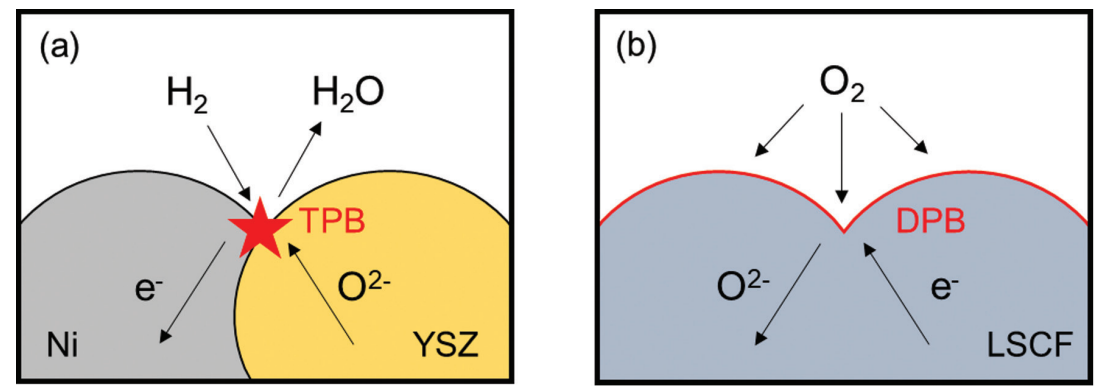

Fig. 2. Schematics depicting the active reaction sites for solid oxide fuel cell electrodes. (a) Triple-phase boundary (TPB), (b) Double-phase boundary (DPB). 
(a)

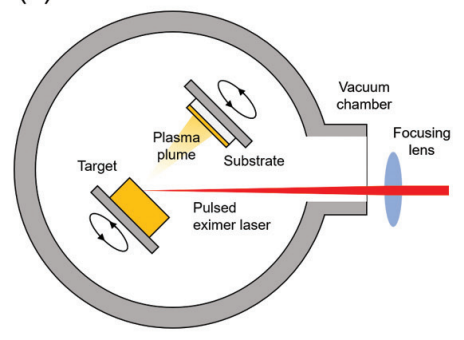

(b)

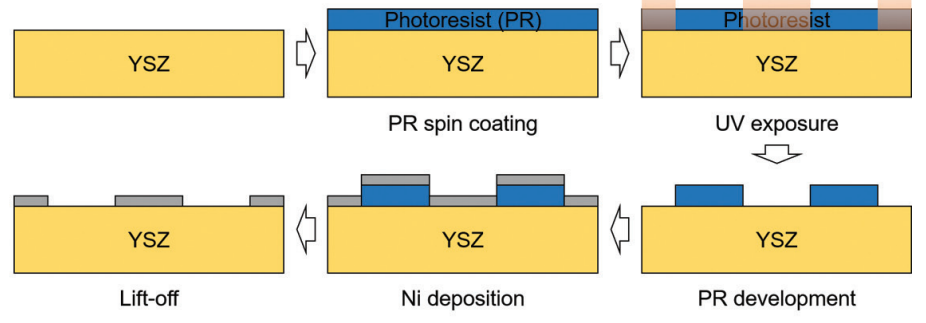

Fig. 3. The fabrication techniques for the model electrodes. (a) Schematic illustration of the pulsed-laser deposition (PLD) for the ceramic thin-films, (b) Schematic illustration of the Ni stripe-pattern fabrication using the lift-off process.

기반의 전극이 많은 주목을 받고 있다. MIEC 기반의 전극에서는 전기화학 반응이 소재 표면 전체, 즉 기체 와 전극이 만나는 2상계면 (double-phase boundary, $\mathrm{DPB}$ )에서 발생하게 되어 훨씬 많은 활성 계면을 제공 할 수 있기 때문이다 (Fig. 2b). 연료극의 $\mathrm{Gd}$ 또는 $\mathrm{Sm}$ doped $\mathrm{CeO}_{2}$, 공기극의 $\mathrm{La}_{0.6} \mathrm{Sr}_{0.4} \mathrm{Co}_{0.2} \mathrm{Fe}_{0.8} \mathrm{O}_{3-\delta}$ (LSCF), $\mathrm{Ba}_{0.5} \mathrm{Sr}_{0.5} \mathrm{Co}_{0.8} \mathrm{Fe}_{0.2} \mathrm{O}_{3-\delta}$ (BSCF), $\mathrm{PrBaCO}_{2-\mathrm{x}} \mathrm{Fe}_{\mathrm{x}} \mathrm{O}_{5+\delta}$ $(\mathrm{PBCF})$ 등의 페로브스카이트계 소재가 대표적인 $\mathrm{MIEC}$ 의 예이다. ${ }^{[13-15]}$

\section{2. 모델 전기화학 셀의 제작 기법}

실제 매우 복잡한 전극을 단순화하여 구현하기 위해 가장 널리 활용되는 기술은 박막 증착 공정과 포토리소 그래피 (photolithography) 기반의 금속 리프트-오프 (lift-off) 패터닝 공정이다. 먼저 높은 퀄리티의 세라 믹 박막을 얻는 것은 모델 전극 연구에서 획득한 정보로 부터 소재의 결정구조, 결정성, 변형도 (strain), 결정립 계 (grain boundary) 밀도, 표면 특성, 결정면 등의 영 향을 다각도로 분석하기 위해 매우 중요하다. 이러한 측 면에서 널리 활용되는 대표적인 고품질 세라믹 박막 증 착 기법 중 하나는 펄스-레이저 증착법 (pulsed laser deposition, PLD)이다. PLD는 물리 증착법 (physical vapor deposition)의 하나로, 펄스 형태의 엑시머 레이 저 (예: $\mathrm{KrF} 248 \mathrm{~nm}$ )를 광학 렌즈를 통해 높은 한 점 에 집중시켜 높은 에너지로 세라믹 타겟에 조사함으로 써 플라즈마를 발생, 원자, 분자, 이온 또는 작은 입자 등으로 구성된 플라즈마 기둥 (plume)이 맞은 편의 기
판에 향하도록 하여 타겟 물질이 기판에 증착되도록 한 다 (Fig. 3a). 이때 레이저의 펄스 주기, 펄스 수, 타겟기판간 거리, 증착 진공도 및 분위기 등의 여러 공정을 제어하여 수 $\mathrm{nm}$ 에서 수 $\mu \mathrm{m}$ 에 이르는 다양한 두께의 단결 정 또는 다결정 세라믹 박막을 획득할 수 있다. 많은 연 구에서 PLD를 통해 타겟의 조성과 크게 일치하는 조성 의 박막을 얻을 수 있다는 것이 잘 알려져 있다. PLD 외 에도 $\mathrm{RF}$ 마그네트론 스퍼터링 역시 널리 활용되고 있는 세라믹 증착기법 방법 중 하나이다.

Fig. 3b는 Fig. 2a에 나타낸 Ni-YSZ 전극의 3상계면 을 모사하기 위한 줄무늬 형태를 갖는 모델 전극을 제작 하는 lift-off 공정 과정을 보여준다. Fig. 3b의 예는 자 외선 노출에 의해 현상액에 녹기 쉽게 화학구조가 변하 는 positive 감광액 (photoresist, PR)의 경우이다. 최 근에는 $0.01 \mathrm{~nm}$ 이하의 매우 짧은 파장의 전자 빔을 이 용한 전자선 리소그래피 (electron beam lithography) 등의 개발으로 수십 $\mathrm{nm}$ 스케일에서 일어나는 현상을 관 찰하기 위한 입자 패터닝 등도 활용되고 있다. ${ }^{[16]}$ 즉, 이 러한 리소그래피 방식의 패터닝 공정을 활용할 경우 필 요에 따라 $\mathrm{nm}$ 에서부터 $\mathrm{mm}$ 스케일의 다양한 전극 계면 구 현이 가능하다. 정리하면, $\mathrm{SOFC}$ 전극에서 일어나는 전 기화학 반응을 연구함에 있어 구조적으로 잘 정의된 활 성 계면을 갖도록 정교하게 제작된 전극을 포함하는 셀 을 모델 전기화학 셀이라고 할 수 있다.

\section{3. 모델 전기화학 셀 분석 기법}

모델 전기화학 셀과의 조합을 통해 전극 반응 매커니 
즘 이해에 대한 강력한 실험적 근거들을 제공할 분석기 법으로는 분극 곡선 (polarization curve), 교류 임피던 스 기법 (AC impedance spectroscopy, ACIS)과 X선 광전자분광기 (X-ray photoelectron spectroscopy) 등이 활용되고 있다. 주로는 반응의 기본 반응 단계들 을 구성, 이들 장비를 활용하여 주변 환경 (온도, 가스 조성 $\left(\mathrm{pH}_{2}, \mathrm{pH}_{2} \mathrm{O}\right)$, 인가 과전압 등)이나 모델 전극 구 조 (전극의 두께 및 간격) 제어에 따라 변하는 전기화학 적 응답 신호나 흡착종 및 전극 조성 변화를 관찰함으로 써 가장 유력한 반응속도 결정단계 (rate-determining step, RDS)를 유추하는 방식이 채택되고 있다. 이밖에 도 여러 기본 반응 단계를 화학반응의 반응속도 식으로 나타내거나 Butler-Volmer 형태의 일반적인 전기화학 반응속도 식으로 표현하여 분극 곡선이나 임피던스 스 팩트럼을 수학적으로 모델링하는 접근법이 모델 전기화 학 셀과 결합하여 반응 매커니즘을 밝히는 좋은 궁합으 로 적극적으로 활용되고 있다. 이는 거시적 관점에서 벌 크나 표면에서의 전극 반응에 수반되는 다양한 물질 전 달 과정을 모델링하는 과정이 단순한 구조의 계면을 가 정할 뿐만 아니라 가능한 반응 경로를 보다 간결하게 나 타낼 수 있으며 필요한 실험적 데이터를 가정 또는 생략 하게 함으로써 계산의 정확도를 높이는 데 기인한다. 이 어지는 제 3 장에서는 다양한 구조의 모델 전기화학 셀을 이용하여 연료극 반응을 연구한 몇 가지 대표 사례에 대 해 알아보겠다.

\section{3. 모델 전기화학 셀 적용 연구 사례}

\subsection{Ni-YSZ cermet 연료극}

$\mathrm{Ni}$-YSZ cermet은 가장 널리 사용되고 있는 연료극 물질로 모델 전극을 활용하여 $\mathrm{H}_{2}$ 또는 $\mathrm{CO}$ 의 전기화학 적 산화 과정에 대한 이해를 목적으로 많은 연구가 수 행되어 왔다. ${ }^{[17,}$ Fig. 4는 대표적으로 관련 연구에서 $\mathrm{Ni}$ 줄무늬 패턴 전극을 이용한 2차원 $\mathrm{Ni}-\mathrm{YSZ}$ 모델 전 극 구조이다. 이러한 전극을 얻기 위해 J. Mizusaki 그 룹은 단결정의 YSZ 기판에 포토리소그래피와 ionized cluster beam 증착법을 이용하였다. ${ }^{[19]}$ 그들은 모델 전
극이 포함된 3 전극 기반의 정상 상태 분극-전류밀도 측 정을 통해 $700^{\circ} \mathrm{C}$ 에서의 전기화학 반응속도를 실험적으 로 $\mathrm{pH}_{2}, \mathrm{pH}_{2} \mathrm{O}$ 및 산소 활동도 $\left(\mathrm{a}_{\mathrm{O}}\right)$ 에 대한 수식으로 표 현하였고, 결과적으로 니켈 표면에서의 흡착 또는 확 산 과정이 속도 결정 단계임을 실험적으로 보였다. J. Gauckler 그룹의 일련의 연구는 또 다른 대표적인 예 로, ${ }^{[20,21]}$ 그들은 마찬가지로 줄무늬 $\mathrm{Ni}$ 패턴 제작을 통 해, $\mathrm{Ni}$ 의 노출 면적은 동일하되 $\mathrm{TPB}$ 의 길이만을 0.04 $\sim 12.85 \mathrm{~m} / \mathrm{cm}^{2}$ 의 범위를 갖도록 하였다. 이러한 모델 전극을 사용한 임피던스 분석법을 통해 정교하게 제어 한 TPB 길이에 선형으로 반비례하는 분극 저항을 확인 함으로써 실제 Ni-YSZ-gas 3상계면이 활성 계면임 을 명확히 하였다. 또한 그들은 분극 저항 활성화에너지 및 가스 분압에 대한 의존성으로부터 Ni-YSZ에서 일 어나는 수소 산화반응 속도를 결정짓는 가장 주요 과정 을 수소의 흡.탈착 또는 전해질로부터 산소 이온의 제 거 과정임을 제안하였다. 더욱이 이 과정이 $\mathrm{H}_{2} \mathrm{O}$ 에 의 해 어떻게 촉진될 수 있는지 그 매커니즘을 제안하였는 데, 연료에 함께 주입하는 $\mathrm{H}_{2} \mathrm{O}$ 로 인한 연료극 $\mathrm{pO}_{2}$ 의 증 가에도 불구하고 $\mathrm{Ni}-\mathrm{YSZ}$ cermet 전극의 성능을 향상 시키는 현상을 TPB에서 YSZ표면으로의 반응 계면 확 대로 설명하였다. 이어 앞서 설명한 J. Gaukler 그룹의 실험 결과를 총 일곱 가지의 서로 다른 반응 경로를 다 룬 수학적 계산을 통해 재현 및 비교하는 모델링 연구가 W. G. Bessler그룹에 의해, ${ }^{[22]}$ J. Mizusaki 그룹의 실 험 결과를 세 가지 반응 경로로 계산하는 연구가 R. J. $\mathrm{Kee}$ 그룹에 의해 각각 수행되었다. ${ }^{[23]}$ 비록 상당히 상이 한 실험 결과를 각각 모델링했음에도 그들의 결과를 통 해 공통적으로 $\mathrm{Ni}-\mathrm{YSZ}$ 연료극에서 수소의 산화반응이 $\mathrm{H}$ spillover 매커니즘으로 설명 가능하다는 사실을 보여 주었다.

한편 이러한 모델 전극 구조의 고온환경 구조적 안 정성은 정확한 실험을 위해 매우 중요하다. 특히 금속 의 응집은 관찰하고자 하는 $\mathrm{TPB}$ 길이에 직접적인 영향 을 주는 요인이다. 이점에 주목하여 I. Ivers-Tiffeé 그 룹은 $\mathrm{Ni}-\mathrm{YSZ}-\mathrm{H}_{2}$ 계면 구조에 대한 가습 및 온도의 영 향을 체계적으로 분석하여, $700^{\circ} \mathrm{C}$ 이상의 고온 영역에 


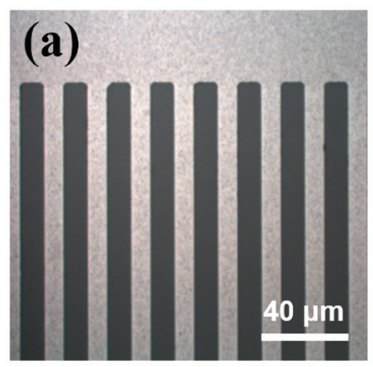

(c)
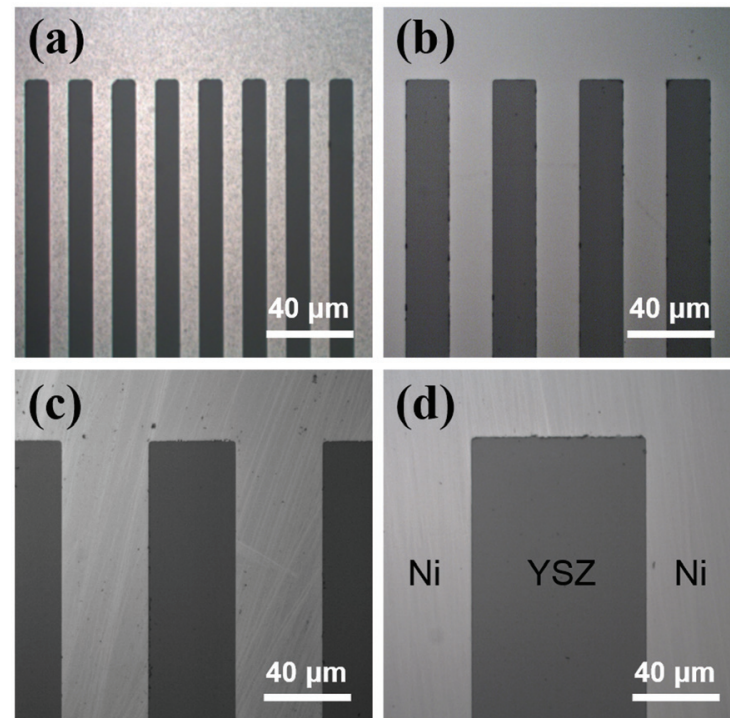

(d)

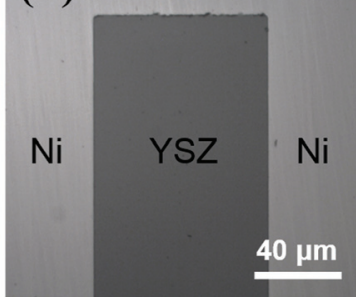

Fig. 4. Optical microscope images of the patterned $\mathrm{Ni}-\mathrm{YSZ}$ model anodes where the widths of Ni and YSZ are (a) 1010, (b) 20-20, (c) 40-40, and (d) 80-80 $\mu \mathrm{m}$, respectively. The corresponding TPB lengths are (a) 6.448, (b) 3.248, (c) 1.648 , and (d) $0.848 \mathrm{~m} \mathrm{~cm}^{-2}$, respectively, Adapted from Jung et al. Nano Energy 2016;23;161-71, with permission of Elsevier S\&T Journals [27]

서의 모델 전극 활용을 위해서는 $0.8 \mu \mathrm{m}$ 이상의 $\mathrm{Ni}$ 두께 를 사용할 것을 제안하였다. ${ }^{[24]}$ 또한 그들은 고온에 노 출된 금속 $\mathrm{Ni}$ 박막의 구조적 재구성이 수증기를 포함하 는 다양한 환경에 크게 의존한다는 점을 들어 초기 제작 한 패턴 구조의 $\mathrm{TPB}$ 길이와 장기 분석 후 $\mathrm{TPB}$ 길이 변 화를 감안한 보정 지수 (correction factor) 등을 고려해 야 한다고 설명하였다. 이후 E. Croiset은 유사한 연구 를 수행하였는데, 다른 두께로 패터닝된 $\mathrm{Ni}$ 전극에 대한
온도 및 가스 환경에서의 미세구조 변화를 관찰하여 가 습 환경에서 $\mathrm{Ni}$ 응집 가속 현상을 확인하였으며, 안정적 셀 평가를 위해 $0.8 \mu \mathrm{m}$ 두께의 $\mathrm{Ni}$ 에 대한 750 또는 800 ${ }^{\circ} \mathrm{C}$ 수소 분위기에서의 사전 열처리가 도움을 줄 수 있음 을 보였다. ${ }^{[25]}$

$\mathrm{Ni}-\mathrm{YSZ}$ 전극에 대한 촉매 도입, 코팅층 도입 등 다 양한 표면 처리 기술은 연료극의 성능 또는 내구성을 향 상시키기 위해 매우 광범위하게 연구되어 왔다. ${ }^{[26]}$ 그러 나 앞서 언급한 바와 같이 Ni-YSZ cermet의 구조적 복 잡성으로 인해 도입한 촉매 또는 코팅층의 역할을 정밀 하게 분석하는 데에는 한계가 있다. W. Jung은 도입한 $\mathrm{Sm}$-doped $\mathrm{CeO}_{2}(\mathrm{SDC})$ 촉매층의 특성을 $\mathrm{Ni}-\mathrm{YSZ}$ 자 체의 구조적 요인으로부터 배제하여 평가하기 위해 줄 무늬 Ni-YSZ 모델 전극을 활용하였으며 (Fig. 5), 이 로부터 나노구조 $\mathrm{SDC}$ 층의 형상의 영향과 촉매층 도입 전/후의 반응 활성점 변화를 관찰하거나 $\mathrm{Ni}$ 의 촉매적 기 여 없이 SDC 표면에서 수소 또는 메탄의 전기화학적 산 화반응이 일어날 수 있다는 사실 등을 확인하였다. ${ }^{[27,28]}$

\section{2. $\mathrm{CeO}_{2}$ 전해질 기반 연료극}

세리아 $\left(\mathrm{CeO}_{2}\right)$ 는 결정 내 $\mathrm{Ce}^{4+}$ 를 $\mathrm{Sm}^{3+}, \mathrm{Gd}^{3+}$ 와 같 은 억셉터 치환을 통해 산소 기공을 형성, YSZ보다 더 높은 산소 전도도를 갖는 물질로 $\mathrm{SOFC}$ 분야에서 활발 히 연구되어온 대표적인 소재이다. 특히 세리아는 YSZ 와 달리 고온의 환원분위기에서 $\mathrm{Ce}^{4+}$ 의 환원으로 형성 된 small polaron $\left(\mathrm{Ce}^{3+}\right.$ 에 해당)의 hopping을 통해 전 자 전도가 가능한 혼합전도 특성을 갖는 것을 특징으로
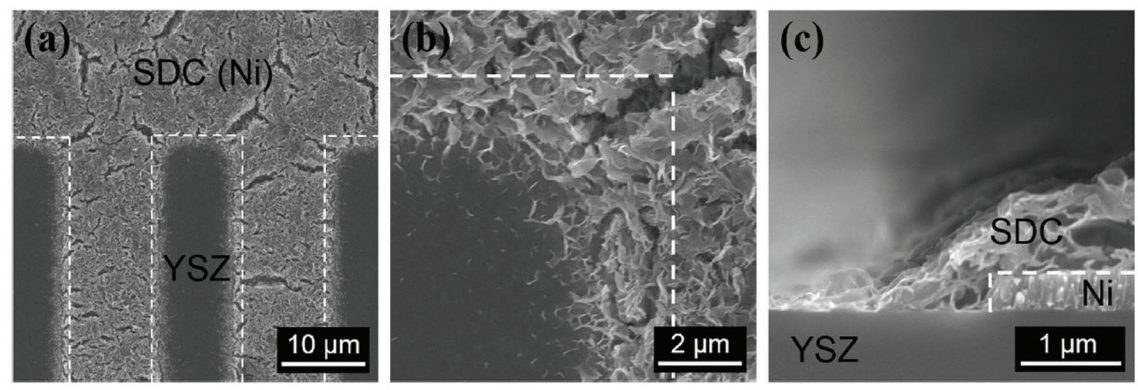

Fig. 5. SEM images of SDC coated patterned Ni-YSZ anode. The white dashed line indicates the underneath Ni patterns, Adapted from Jung et al. Nano Energy 2016;23;161-71, with permission of Elsevier S\&T Journals [27] 


\section{특 집 ㅁㅃ 최윤석}

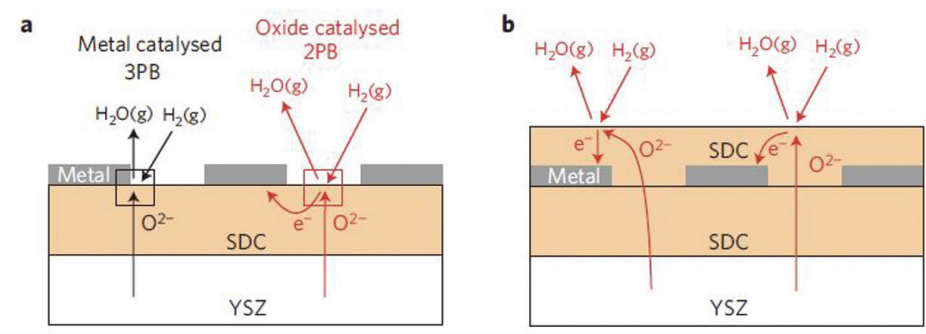

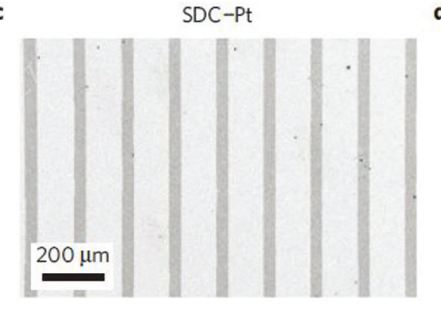

f

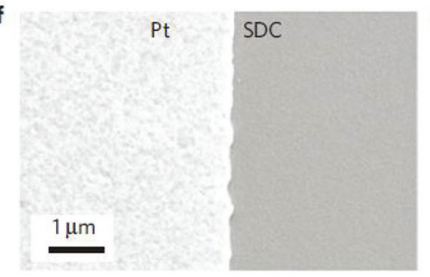

d

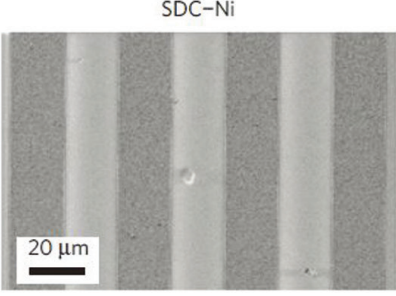

e
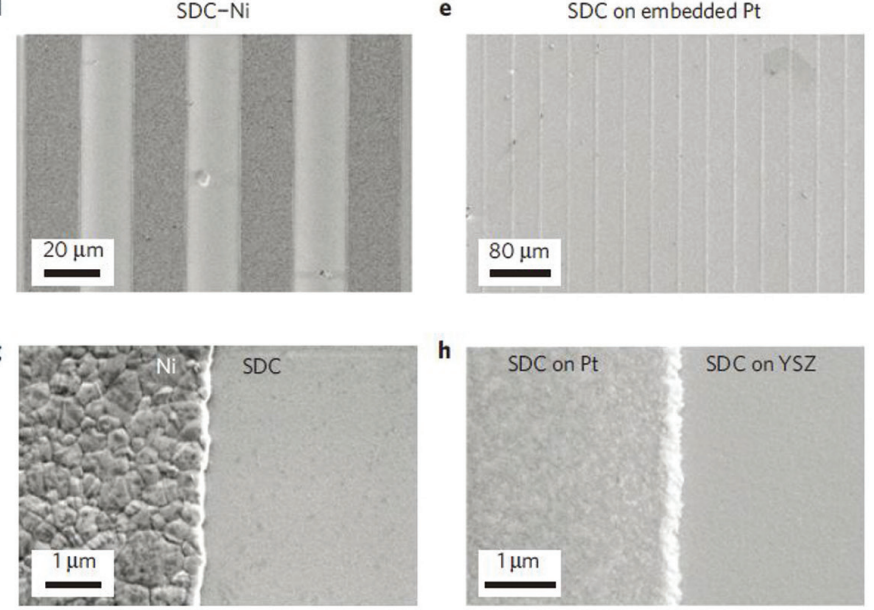

SDC on YSZ

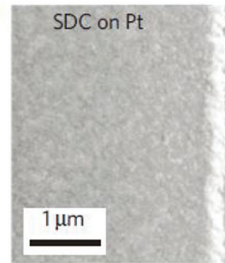

SDC ONYSZ
Fig. 6. Schematics depicting the two reaction sites in the patterned metal-SDC electrodes, (a) the metal-exposed sample and (b) the metal embedded sample, respectively. (c-h) The SEM images of the corresponding model electrode structures, Adapted from Haile et al. Nat Mater 2012;11;155-61, with permission of Springer Nature [30]
한다. ${ }^{[29]}$ 이는 앞서 2.1장에서 언급한 MIEC에 해당하는 것으로, 연료극에 적용될 경우 세리아 표면 전체가 반응 에 참여하는 활성 계면이 되어 우수한 전극 성능을 구현 하는 것이 가능하다. 이러한 특성에 대해 S. M. Haile 그룹은 실제로 Fig. 6과 같이 PLD와 금속 lift-off 공 정을 이용하여 metal/SDC/gas 3상계면의 밀도 $\left(\mathrm{d}_{\mathrm{TPB}}\right)$ 와 $\mathrm{SDC} / \mathrm{gas} 2$ 상계면의 밀도 $\left(\mathrm{d}_{\mathrm{DPB}}\right)$ 를 제어한 다양한 모 델 전극 구조를 제작하였다. ${ }^{[0]}$ 임피던스 분석을 통해 분극 저항과 계면 밀도와의 상관 관계를 명확히 함으로 써 $\mathrm{SDC}$ 가 포함된 연료극에 대한 지배적인 반응 경로가 $\mathrm{SDC}$ 표면임을 증명하였다. 그들의 임피던스 결과는 후 에 F. Ciucci 그룹의 2D 수치해석 모델링 의해 매우 일 치되게 재현되었으며, $\mathrm{SDC}$ 의 두께, 금속 패턴 간격 등 모델 전극 구조에 따라 달라지는 임피던스를 산소 결함 과 전자의 전달 과정, 표면 반응성 등으로 정량적으로
구분함으로써 보다 정확한 연구를 위한 모델 전극 구조 설계의 중요성에 대한 이론적 근거를 제공하였다. ${ }^{[31,32]}$

이후 SDC 표면에서 발생하는 수소 산화/수증기 분해 반응 경로에 대한 반응 매커니즘은 W. Eichhorn 그룹 과 W. Chueh 그룹에 의해 서로 다른 구조의 모델 전극 과 in operando X-ray photoelectron spectroscopy (XPS)를 이용해 실험적으로 연구되었다. W. Eichhorn 그룹은 Fig. 7a과 같이 in-plane 방향으로 전압을 인가 할 수 있는 약 $50 \mathrm{~nm}$ 의 두께로 제작된 모델 전극을 제작 하였다. 그들은 $750^{\circ} \mathrm{C} 1 \mathrm{mbar}$ 의 $\mathrm{H}_{2} / \mathrm{H}_{2} \mathrm{O}$ 가스 환경에서 전압을 인가함에 따라 달라지는 binding energy 이동, $\mathrm{Ce}^{4+} / \mathrm{Ce}^{3+}$ 의 산화 상태를 분석함으로써 금속 전극으로 부터 벗어난 약 $150 \mu \mathrm{m}$ 의 SDC 활성 영역을 확인하였고, 결과적으로 표면 반응성과 세리아 박막 내 전자의 전달 과정이 동시에 전체 반응 속도를 결정한다는 결과를 발 
(a)

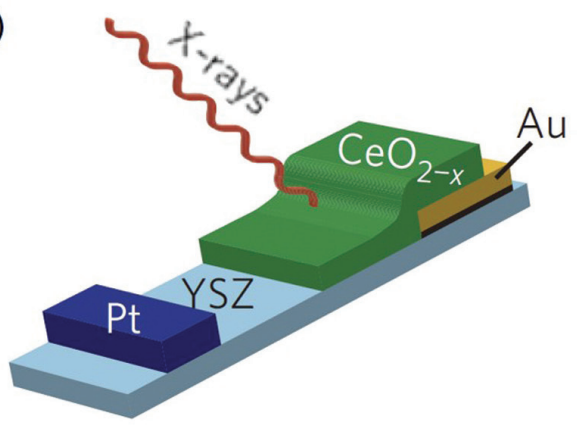

a

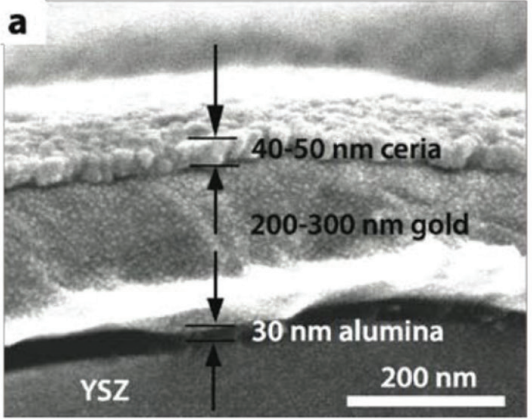

(b)

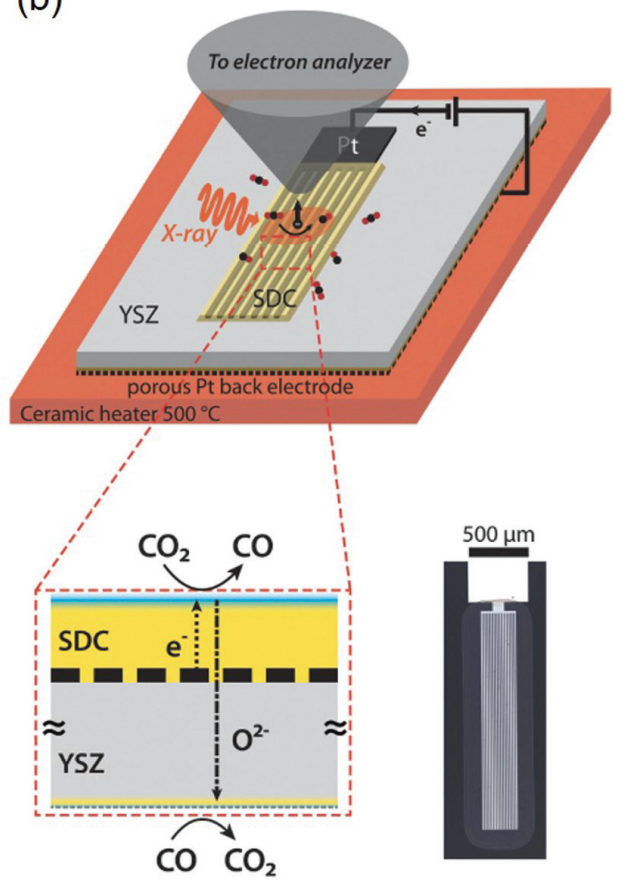

Fig. 7. Two different types of the model electrochemical cells with the ceria thin-film electrodes for in operando XPS studies. (a) The cell with the in-plane $\mathrm{O}^{2-}$ transport pathway, Reproduced from Eichhorn et al. Nat Mater 2010;9;944-49, with permission of Springer Nature [33], (b) The cell with the out-of-plane $\mathrm{O}^{2-}$ transport pathway, Adapted from Chueh et al. Phys Chem Chem Phys 2015;17;12273, with permission of Royal Society of Chemistry [35]

표하였다. ${ }^{[33]}$ 한편 $\mathrm{W}$. Chueh 그룹은 인가된 전압 강하 가 오직 $\mathrm{SDC} / \mathrm{gas}$ 계면에서 발생하도록 하는 표면 반응 지배형 모델 전기화학 셀을 제작하여 정교하게 표면 반 응만을 관찰하였다 (Fig. 7b). ${ }^{[34,35]} 500^{\circ} \mathrm{C} 0.3$ Torr의 $\mathrm{H}_{2} / \mathrm{H}_{2} \mathrm{O}$ 가스 환경에서 $\mathrm{SDC}$ 표면에서의 전기화학적 수 소 산화/수증기 분해 중 산소 이온의 전달이 표면에 응 집되어 존재하는 산소 기공을 통해 매우 빠르게 발생한 다는 사실을 밝혔으며, 동시에 상대적으로 전자의 전달 과정이 전체 반응 속도를 결정한다는 실험적 근거를 제 시하였다.

최근 $\mathrm{W}$. Jung 그룹은 $\mathrm{SDC}$ 와 같은 $\mathrm{MIEC}$ 의 표면에 도입된 금속 나노입자가 수소의 산화반응 (또는 반대)을 크게 향상시킬 수 있다는 사실에 주목하여, 그들의 전기 화학적 촉매 특성을 정량적으로 파악하기 위한 나노 단 위 모델 시스템을 제작하였다. 그들의 모델 전기화학 셀 은 Fig. 8과 같이 일정하게 노출된 $\mathrm{SDC}$ 전극 위에 블록
공중합체 (Block copolymer)를 이용한 리소그래피 방 식으로 일정한 간격을 지니고 거의 동일한 크기를 갖도 록 금속 나노입자를 패터닝하였다. ${ }^{[36]}$ 이와 같이 주요 활 성 계면을 정량화할 수 있는 나노 단위 모델 전극을 플 랫폼화 할 경우 단순히 분극 저항의 크기를 비교하여 나 노 촉매의 성능을 비교 분석하거나 촉매의 역할을 규명 하는 것이 가능함을 보고하였다.

\subsection{Perovskite계 산화물 연료극}

비록 $\mathrm{Ni}$ 은 환원분위기의 연료극에 가장 널리 사용되 는 촉매이자 전자 전도체이지만 탄화수소와 같은 연료 또는 가습의 가스 분위기 등에서 화학적 불안정성으로 인해 열화가 가속되는 문제가 있다. 이러한 이유로 많은 연구자들은 니켈을 대체할 수 있는 MIEC 산화물 연료 극을 개발하는 데 많은 노력을 쏟고 있다. ${ }^{[37]}$ 모델 전기 화학 셀은 이러한 산화물 연료극의 물성, 반응 경로, 화 


\section{특 집 ㅁㅃ쵳윤석}

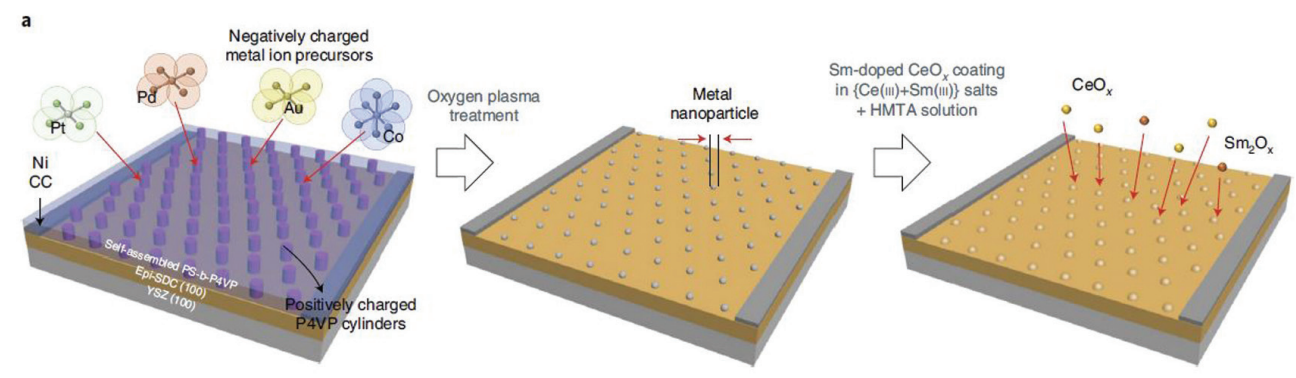

b

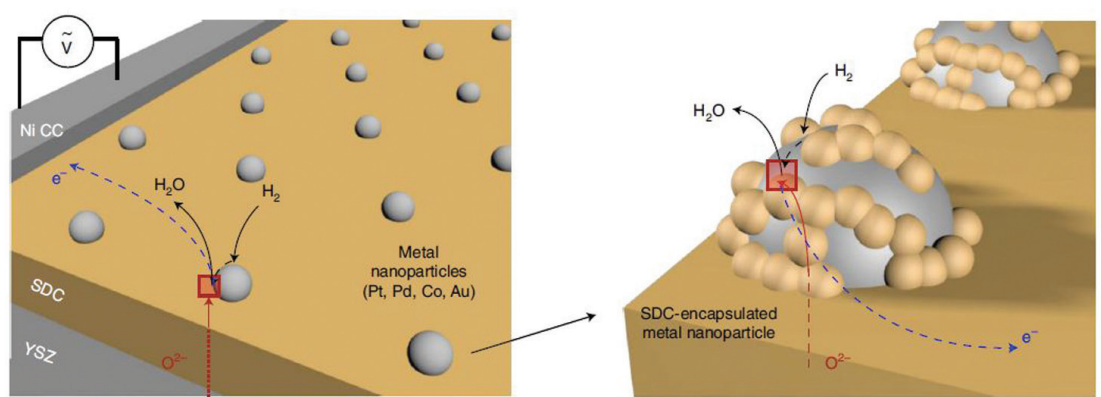

Fig. 8. Schematic flowchart of the fabrication process for the model Ni-SDC anodes decorated with the monoarray of metal nanoparticles obtained via block-copolymer lithography. Adapted from Jung et al. Nat Nanotech. 2019;14;245-51, with permission of Springer Nature [36]

학적 안정성 등을 정밀하게 파악하는 데 중요한 역할을 하고 있다. J. Fleig 그룹은 $\mathrm{Sr}(\mathrm{TiFe}) \mathrm{O}_{3-\delta}(\mathrm{STF}){ }^{[38,39]}$ $\mathrm{La}_{0.75} \mathrm{Sr}_{0,25} \mathrm{Cr}_{0.5} \mathrm{Mn}_{0.5} \mathrm{O}_{3 \pm \delta}$ (LSCM), ${ }^{[40]} \mathrm{La}_{0.6} \mathrm{Sr}_{0.4} \mathrm{FeO}_{3-\delta}$ $(\mathrm{LSF}){ }^{[41,42]}$ 등의 perovskite계 산화물 연료극에 대한 임피던스 분석법, in situ XPS, in situ XRD 등의 다 양한 기법을 모델 전기화학 셀과 연계하여 활발한 연 구를 수행하고 있다. 그들은 [38]에서 환원분위기에서 대게 낮은 전자 전도도를 갖는 $\mathrm{MIEC}$ 연료극을 연구하 기 위한 모델 전기화학 셀의 구조적 설계와 임피던스 해석을 위한 등가 회로에 대해 논의하였다. 특히 최근 perovskite계 산화물 연료극의 가장 큰 화두 중 하나는 exsolution (용출 현상)의 활용과 이 현상에 대한 심도 있는 이해로, ${ }^{[43,44]}$ 다양한 소재 특성으로부터 나노 입자 의 exsolution을 제어하고, 이를 정량적으로 표면 전기 화학적 촉매 특성과 연계하기 위해 산화물 박막 기반의 모델링 연구가 활발히 이루어지고 있다. 최근 J. Fleig 그룹의 [45] 연구에서는 LSF 모델 전극에 대한 in situ $\mathrm{XRD}$ 분석을 통해 표면에 용출된 $\mathrm{Fe}$ 의 상의 조성 변화 가 전기화학적 특성에 미치는 영향을 확인하였다. 그들
의 결과에 따르면, (산화과 환원) 전환 가능한 촉매는 궁 극적으로 $\mathrm{Fe}$ 의 모상으로의 복귀 (reintegration) 또는 재용출이 아닌 용출된 $\mathrm{Fe}$ 입자의 금속상으로의 전환이 결정적인 성능 향상 요인임을 밝혔다.

\section{4. 결론}

차세대 친환경 발전 장치로 주목받고 있는 고체산화 물 연료전지의 높은 성능 구현을 위해 고활성 전극 개발 은 필수적이다. 이 투고문에서는 고성능 전극 개발을 위 해 전극 반응에 대한 깊이 있는 이해를 목적으로 활용되 고 있는 구조적으로 잘 정의된 계면을 갖는 모델 전극의 제작과 관련 연구 결과들에 대해 설명하였다. 가장 활 발한 연구가 수행되어 온 연료극을 예로 살펴본 바와 같 이 모델링 접근법은 다공성의 구조로 인해 파악하기 힘 든 소재 고유의 물성을 정량적으로 파악하거나 매우 복 잡하게 일어나는 전극 표면에서의 전기화학반응 매커니 즘을 연구한 데 큰 역할을 하고 있다. 한편 본문에서 다 루지 않았지만 또다른 중요 전극 반응인 산소환원과정 
에 대한 공기극 연구도 활발히 연구되고 있다. 최근에 는 모델 전기화학 셀을 기반으로 한 in operando 분석 기술이 주목 받고 있으며 전통적인 전기화학적 분석만 으로 부족한 전극 반응에 대한 보다 다양한 정보를 얻을 수 있다. 또한 모델 전극은 패터닝 기술의 발전과 함께 보다 정교한 실험 설계가 가능해졌으며, 금속 나노입자 함침, exsolution 등과 같이 그 중요성이 날로 증가하고 있는 $\mathrm{SOFC}$ 전극에 대한 나노 촉매의 활용 연구에도 그 활용도가 계속해서 증가할 것으로 기대된다.

\section{Acknowledgement}

이 논문은 2021년도 대한민국 정부(과학기술정보 통신부)의 재원으로 한국연구재단 미래수소원천기술 개발사업의 지원을 받아 수행된 연구임 (과제번호 : 2021M3I3A1084931)

\section{REFERENCES}

1. Fuel Cell Handbook. EG\&G Technical Services, Inc. 2004

2. N. Q. Minh, "Ceramic fuel-cells". J. Am. Ceram. Soc., 76 [3] 563-88 (1993).

3. S. C. Singhal and K. Kendall, High Temperature Solid Oxide Fuel Cells: fundamentals, design, and applications. New York: Elsevier Advanced Technology. 2003

4. E. P. Murray, T. Tsai, and S. A. Barnett, "A directmethane fuel cell with a ceria-based anode". Nature, 400 [6745] 649-51 (1999).

5. S. D. Park, J. M. Vohs, and R. J. Gorte, "Direct oxidation of hydrocarbons in a solid-oxide fuel cell". Nature, 404 [6775] 265-67 (2000).

6. S. McIntosh and R. J. Gorte, "Direct hydrocarbon solid oxide fuel cells". Chem. Rev., 104 [10] 4845-65 (2004).

7. E. D. Wachsman and K. T. Lee, "Lowering the Temperature of Solid Oxide Fuel Cells". Science, 334 [6058] 935-39 (2011).

8. T. Van Gestel, F. Han, D. Sebold, H. P. Buchkremer, and D. Stover, "Nano-structured solid oxide fuel cell design with superior power output at high and intermediate operation temperatures". Microsyst. Technol., 17 [2] 233-42 (2011).

9. J. G. Lee, J. H. Park, and Y. G. Shul, "Tailoring gadolinium-doped ceria-based solid oxide fuel cells to achieve $2 \mathrm{Wcm}^{-2}$ at $550^{\circ} \mathrm{C}$ ". Nat. Commun., 54045 (2014).

10. K. T. Lee and E. D. Wachsman, "Role of nanostructures on SOFC performance at reduced temperatures". Mrs Bulletin., 39 [9] 783-91 (2014).

11. W. Jung and H. L. Tuller, "A New Model Describing Solid Oxide Fuel Cell Cathode Kinetics: Model Thin Film $\mathrm{SrTi}_{1-\mathrm{x}} \mathrm{Fe}_{\mathrm{x}} \mathrm{O}_{3-\mathrm{d}}$ Mixed Conducting Oxides-a Case Study". Adv. Energy Mater, 1 [6] 1184-91 (2011).

12. W. Lai and S. M. Haile, "Impedance spectroscopy as a tool for chemical and electrochemical analysis of mixed conductors: A case study of ceria". J. Am. Ceram. Soc., 88 [11] 2979-97 (2005).

13. J. Rossmeisl and W. G. Bessler, "Trends in catalytic activity for SOFC anode materials". Solid State Ion., 178 [31-32] 1694-700 (2008).

14. A. J. Jacobson, "Materials for Solid Oxide Fuel Cells". Chem. Mater., 22 [3] 660-74 (2010).

15. C. W. Sun, R. Hui, and J. Roller, "Cathode materials for solid oxide fuel cells: a review". J. Solid State Electrochem., 14 [7] 1125-44 (2010).

16. C. M. Chuang, M. C. Wu, Y. C. Huang, K. C. Cheng, C. F. Lin, Y. F. Chen, and W. F. Su, "Nanolithography made from water-based spin-coatable LSMO resist". Nanotech., 17 [17] 4399-404 (2006).

17. W. G. Bessler, M. Vogler, H. Stoermer, D. Gerthsen, A. Utz, A. Weber, and E. Ivers-Tiffee, "Model anodes and anode models for understanding the mechanism of hydrogen oxidation in solid oxide fuel cells". Phys. Chem. Chem. Phys., 12 [42] 13888-903 (2010).

18. V. Yurkiv, A. Utz, A. Weber, E. Ivers-Tiffee, H. R. Volpp, and W. G. Bessler, "Elementary kinetic modeling and experimental validation of electrochemical $\mathrm{CO}$ oxidation on $\mathrm{Ni} / \mathrm{YSZ}$ pattern anodes". Electrochim. Acta., 59 573-80 (2012).

19. J. Mizusaki, H. Tagawa, T. Saito, T. Yamamura, K. Kamitani, K. Hirano, S. Ehara, T. Takagi, T. Hikita, M. Ippommatsu, S. Nakagawa, and K. Hashimoto, "Kinetic-studies of the reaction at the nickel pattern electrode on $\mathrm{YSZ}$ in $\mathrm{H}_{2}-\mathrm{H}_{2} \mathrm{O}$ atmospheres". Solid State Ion., 70 52-8 (1994). 
20. A. Bieberle and L. J. Gauckler, "Reaction mechanism of Ni pattern anodes for solid oxide fuel cells". Solid State Ion., 135 [1-4] 337-45 (2000).

21. A. Bieberle, L. P. Meier, and L. J. Gauckler, "The electrochemistry of Ni pattern anodes used as solid oxide fuel cell model electrodes". J. Electrochem. Soc., 148 [6] A646-A56 (2001).

22. M. Vogler, A. Bieberle-Hutter, L. Gauckler, J. Warnatz, and W. G. Bessler, "Modelling Study of Surface Reactions, Diffusion, and Spillover at a Ni/ YSZ Patterned Anode". J. Electrochem. Soc., 156 [5] B663-B72 (2009).

23. D. G. Goodwin, H. Y. Zhu, A. M. Colclasure, and R. J. Kee, "Modeling Electrochemical Oxidation of Hydrogen on Ni-YSZ Pattern Anodes". $J$. Electrochem. Soc., 156 [9] B1004-B21 (2009).

24. A. Utz, H. Stormer, D. Gerthsen, A. Weber, and E. Ivers-Tiffee, "Microstructure stability studies of $\mathrm{Ni}$ patterned anodes for SOFC". Solid State Ion., 192 [1] 565-70 (2011).

25. W. F. Yao and E. Croiset, "Stability and Electrochemical Performance of Ni/YSZ Pattern Anodes in H-2/H2O Atmosphere". Can. J. Chem. Eng., 93 [12] 2157-67 (2015).

26. Z. B. Liu, B. B. Liu, D. Ding, M. F. Liu, F. L. Chen, and C. R. Xia, "Fabrication and modification of solid oxide fuel cell anodes via wet impregnation/infiltration technique". J. Power Sources, 237 243-59 (2013).

27. Y. Choi, E. C. Brown, S. M. Haile, and W. Jung, "Electrochemically modified, robust solid oxide fuel cell anode for direct-hydrocarbon utilization". Nano Energy, 23 161-71 (2016).

28. Y. Choi, J. Kim, H. G. Seo, H. L. Tuller, and W. Jung, "Nucleation and growth kinetics of electrochemically deposited ceria nanostructures for high-temperature electrocatalysis". Electrochim. Acta., 316 273-82 (2019).

29. H. L. Tuller and A. S. Nowick, "Small polaron electron-transport in reduced $\mathrm{CeO}_{2}$ single-crystals ". $J$. Phys. Chem. Solids, 38 [8] 859-67 (1977).

30. W. C. Chueh, Y. Hao, W. Jung, and S. M. Haile, "High electrochemical activity of the oxide phase in model ceria-Pt and ceria-Ni composite anodes". Nat. Mater., 11 [2] 155-61 (2012).

31. C. Chen, D. Chen, W. C. Chueh, and F. Ciucci, "Modeling the impedance response of mixed- conducting thin film electrodes". Phys. Chem. Chem. Phys., 16 [23] 11573-83 (2014).

32. J. P. Liu and F. Ciucci, "Modeling the impedance spectra of mixed conducting thin films with exposed and embedded current collectors". Phys. Chem. Chem. Phys., 19 [38] 26310-21 (2017).

33. C. J. Zhang, M. E. Grass, A. H. McDaniel, S. C. DeCaluwe, F. El Gabaly, Z. Liu, K. F. McCarty, R. L. Farrow, M. A. Linne, Z. Hussain, G. S. Jackson, H. Bluhm, and B. W. Eichhorn, "Measuring fundamental properties in operating solid oxide electrochemical cells by using in situ X-ray photoelectron spectroscopy". Nat. Mater., 9 [11] 944-49 (2010).

34. Z. A. Feng, F. El Gabaly, X. Ye, Z.-X. Shen, and W. C. Chueh, "Fast vacancy-mediated oxygen ion incorporation across the ceria-gas electrochemical interface". Nat Commun., 54374 (2014).

35. Z. A. Feng, M. L. Machala, and W. C. Chueh, "Surface electrochemistry of $\mathrm{CO}_{2}$ reduction and $\mathrm{CO}$ oxidation on $\mathrm{Sm}$-doped $\mathrm{CeO}_{2-\mathrm{x}}$ : coupling between $\mathrm{Ce}^{3+}$ and carbonate adsorbates". Phys. Chem. Chem. Phys., 17 [18] 12273-81 (2015).

36. Y. Choi, S. K. Cha, H. Ha, S. Lee, H. K. Seo, J. Y. Lee, H. Y. Kim, S. O. Kim, and W. Jung, "Unravelling inherent electrocatalysis of mixed-conducting oxide activated by metal nanoparticle for fuel cell electrodes". Nat. Nanotech., 14 [3] 245-51 (2019).

37. X. M. Ge, S. H. Chan, Q. L. Liu, and Q. Sun, "Solid Oxide Fuel Cell Anode Materials for Direct Hydrocarbon Utilization". Adv. Energy Mater, 2 [10] 1156-81 (2012).

38. A. Nenning, A. K. Opitz, T. M. Huber, and J. Fleig, "A novel approach for analyzing electrochemical properties of mixed conducting solid oxide fuel cell anode materials by impedance spectroscopy". Phys. Chem. Chem. Phys., 16 [40] 22321-36 (2014).

39. A. Nenning, L. Volgger, E. Miller, L. V. Mogni, S. Barnett, and J. Fleig, "The Electrochemical Properties of $\mathrm{Sr}(\mathrm{Ti}, \mathrm{Fe}) \mathrm{O}_{3-\delta}$ for Anodes in Solid Oxide Fuel Cells". J. Electrochem. Soc., 164 [4] F364-F71 (2017).

40. A. K. Huber, M. Falk, M. Rohnke, B. Luerssen, L. Gregoratti, M. Amati, and J. Janek, "In situ study of electrochemical activation and surface segregation of the SOFC electrode material $\mathrm{La}_{0.75} \mathrm{Sr}_{0.25} \mathrm{Cr}_{0.5} \mathrm{Mn}_{0.5} \mathrm{O}_{3-\delta}$ “. Phys. Chem. Chem. Phys., 14 [2] $751-58$ (2012).

41.A. K. Opitz, A. Nenning, C. Rameshan, R. 
Rameshan, R. Blume, M. Havecker, A. KnopGericke, G. Rupprechter, J. Fleig, and B. Klotzer, "Enhancing Electrochemical Water-Splitting Kinetics by Polarization-Driven Formation of Near-Surface Iron(0): An In Situ XPS Study on Perovskite-Type Electrodes". Angew. Chem.-Int. Edit., 54 [9] 2628-32 (2015).

42. A. Nenning, A.K. Opitz, C. Rameshan, R. Rameshan, R. Blume, M. Havecker, A. Knop-Gericke, G. Rupprechter, B. Klotzer, and J. Fleigt, "Ambient Pressure XPS Study of Mixed Conducting PerovskiteType SOFC Cathode and Anode Materials under Well-
Defined Electrochemical Polarization". J. Phys. Chem. C., 120 [3] 1461-71 (2016).

43. J. K. Kim, Y. R. Jo, S. Kim, B. Koo, J. H. Kim, B. J. Kim, and W. Jung, "Exceptional Tunability over Size and Density of Spontaneously Formed Nanoparticles via Nucleation Dynamics". ACS Appl. Mater. Interfaces, 12 [21] 24039-47 (2020).

44. J. H. Kim, J. K. Kim, J. Liu, A. Curcio, J. S. Jang, I.D. Kim, F. Ciucci, and W. Jung, "Nanoparticle Ex-solution for Supported Catalysts: Materials Design, Mechanism and Future Perspectives". ACS Nano, 15 [1] 81-110 (2021).

\section{최 윤 석}

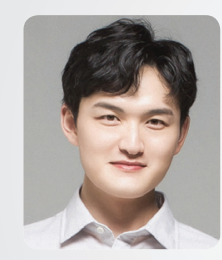

- 2013년 한양대학교 신소재공학부 학사

○ 2015년 KAIST 신소재공학과 석사

( 2019년 KAIST 신소재공학과 박사

○ 2019년 3월 - 9월 KAIST 응용과학연구소 박사후연구원

( 2019년 9월 - 현재 한국에너지기술연구원 에너지소재연구실 선임연구원 